\title{
PENGARUH STATUS GIZI DENGAN KEJADIAN PREEKLAMPSIA IBU HAMIL TRIMESTER III DI PUSKESMAS SIDOTOPO WETAN
}

\author{
Yasi Anggasari \\ (Universitas Nahdlatul Ulama Surabaya, FKK, Prodi D III Kebidanan, \\ Email: yasi@unusa.ac.id) \\ Fitria Dwi Anggraini \\ Universitas Nahdlatul Ulama Surabaya, FKK, Prodi D III Kebidanan, \\ Email: fitria@unusa.ac.id)
}

\begin{abstract}
ABSTRAK
Kehamilan merupakan proses alami bagi seorang wanita, namun pada kenyataannya kehamilan saat ini banyak sekali diiringi dengan komplikasi dalam kehamilan salah satunya dengan preeklampsia yang lebih banyak pada ibu dengan status gizi lebih. Penelitian ini bertujuan untuk mengetahui pengaruh status gizi dengan kejadian preeklampsia ibu hamil trimester III di Puskesmas Sidotopo Wetan. Desain penelitian ini adalah analitik observasional. Populasi pada penelitian ini adalah seluruh ibu hamil trimester III pada bulan juni di Puskesmas Sidotopo Wetan Surabaya sebesar 65 orang, sampel sebesar 30 responden diambil dengan menggunakan teknik Simple Random Sampling. Variabel independen yaitu status gizi, variabel dependen yaitu kejadian preeklampsia. Pengumpulan data menggunakan lembar observasi, pengolahan data melalui editing, scoring, coding, tabulating. Data dianalisis melalui uji staistika Mann Whiney dengan tingkat kemaknaan $\alpha=0,05$. Hassil penelitian menunjukkan bahwa setengah (50\%) responden mempunyai status gizi lebih, dan sebagian besar $(60 \%)$ responden tidak mengalami preeklampsia. Hasil uji Mann Whitney $\rho(0,079)>\alpha(0,05)$, maka $\mathrm{H}_{0}$ diterima artinya tidak ada pengaruh status gizi dengan kejadian preeklampsia pada ibu hamil trimester III Puskesmas Sidotopo Wetan Surabaya. Simpulan dari penelitian ini adalah tidak ada pengaruh status gizi dengan kejadian preeklampsia pada ibu hamil trimester III. Petugas kesehatan terutama bidan lebih meningkatkan upaya pencegahan terhadap kejadian preeklampsia.
\end{abstract}

Kata Kunci : Status Gizi, Preeklampsia

\section{ABSTRACT}

Pregnancy is a natural process for a woman, but in fact pregnancy this time accompanied by a lot of complications in pregnancy one of them with preeklampsia with more in the mother nutritional status of more. This research aims to understand the influence of the nutritional status with the genesis of pregnant women preeclampsia sidotopo wetan in the third trimester. The design of this study is observational analytic. The population in this research is all pregnant women a trimester III in june in Puskesmas Sidotopo Wetan Surabaya of 65 people, of 30 sample of respondents taken by using technique Simple Random Sampling. The independent variable that is the nutritional status, is the dependent variable preeclampsia scene. The collection of data using a sheet of observation, data processing through editing, scoring, as well, tabulating. Data analyzed by 
mann staistika test with the level of whiney significance $\alpha=0,05$. The results of research shows that half the (50\%) of respondents have more nutritional status, and most $(60 \%)$ of respondents did not experience preeclampsia. Mann test whiney $\rho(0,079)>\alpha(0,05)$, then h0 accepted It means no influence on the nutritional status with the third trimester preeklampsia pregnant mothers puskesmas sidotopo wetan surabaya. Drawing conclusions from the study is that there is no influence the nutritional status with the genesis preeclampsia for pregnant women a trimester III. Health workers especially midwives improve preventive efforts against preeclampsia scene.

Key Words : Nutritional Status, Preeclampsia

\section{PENDAHULUAN}

Pada dasarnya, bagi seorang wanita kehamilan merupakan proses alami. Selama proses kehamilan, semua ibu, suami, keluarga dan petugas kesehatan pastinya mengharapkan kehamilan berjalan dengan lancar sampai proses persalinan tiba. Sebuah kehamilan dianggap normal jika tanpa ada penyulit atau komplikasi, akan tetapi cukup banyak ditemukan ibu hamil dengan komplikasi salah satunya adalah preeklampsia. Beberapa ahli menyampaikan bahwa ada beberapa faktor yang dapat mempengaruhi preeklampsia salah satunya obesitas. Menurut Chapman (2006) Ibu Hamil dengan BB berlebih (obesitas) yaitu yang memiliki indeks massa tubuh (IMT) > 29 memiliki resiko terjadi preeklampsia sebesar empat kali lipat dibandingkan dengan ibu hamil dengan IMT normal. Akan tetapi yang terjadi di masyarakat bukan hanya perempuan obesitas yang mengalami preeklampsia, tetapi perempuan dengan indeks masa tubuh normal juga banyak yang mengalami preeklampsia.

Angka kejadian preeklampsia berdasarkan Survey Demografi Kesehatan Indonesia (SDKI) tahun 2012 di Jawa Timur kasus preeklampsia yaitu 12,456 jiwa
(1,98\%), pada tahun 201314,097 jiwa $(2,18 \%)$, sedangkan pada tahun 2014 13,871 jiwa (2,13\%). Di Kota Surabaya kejadian preeklampsia setiaop tahun mengalami peningkatan, pada tahun 2012 sebanyak 767 jiwa (1,78\%), sedangkan pada tahun 20131,051 jiwa (2,27\%), pada tahun 20141,171 jiwa $(2,36 \%)$. Berdasarkan data awal yang diambil oleh peneliti dari rekam medik di Puskesmas Sidotopo Wetan Surabaya pada bulan april 2015, terdapat 16 orang ibu hamil Trimester III yang mengalami preeklampsia, dimana 6 orang $(37 \%)$ dengan obesitas, 8 orang $(50 \%)$ dengan berat badan normal, dan sedangkan hanya 2 orang $(13 \%)$ yang memiiki berat badan kurus.

Menurut Wiknjosastro, $\mathrm{H}$, (2006), terdapat beberapa faktor predisposisi yang mempengaruhi terjadinya preeklampsia di antaranya kehamilan pada wanita umur diatas 35 tahun diabetes mellitus, gemeli, paritas tinggi, molahidatidosa, obesitas. Obesitas merupakan status gizi lebih yang ditandai dengan kenaikan berat badan yang melebihi berat badan normal. Obesitas selain dapat menyebabkan tingginya kadar kolesterol dalam darah juga mempengaruhi kerja jantung, karena semakin gemuk seseorang maka semakin banyak pula jumlah darah 
yang terdapat didalam tubuh sehingga semakin berat juga pompa jantung dan tekanan darahpun meningkat sehingga dapat menimbulkan preeklampsia, tingginya tekanan darah mengakibatkan mengecilnya pembuluh darah di uterus yang dapat berdampak pada berkurangnya suplai oksigen serta nutrisi yang diperlukan. Jika pembuluh darah mengecil maka dampaknya aliran darah ke janin menjadi terganggu dan menghambat perkembangan janin.

Salah satu upaya untuk menurunkan angka kejadian preeklampsia adalah dengan teratur melakukan pemeriksaan ANC, istirahat yang cukup dan asupan nutrisi sesuai yang optimal. Istirahat dalam hal ini, ibu tetap dapat melakukan aktifitas ringan sehari-hari dan membatasi diri dari aktifitas yang melelahkan. Pemenuhan kebutuhan protein yang adekuat sangat dibutuhkan untuk pertumbuhan dan perbaikan sel dan tranformasi lipid, serta menjaga kenaikan berat badan yang berlebihan. (Maryunani, 2012)

Berdasarkan latar belakang terebut, peneliti tertarik untuk menganalisa pengaruh status gizi dengan kejadian preeklampsia pada ibu hamil trimester III di Puskesmas Sidotopo Wetan Surabaya.

\section{METODE PENELITIAN}

Penelitian ini merupakan penelitian analitik observasional, yaitu jenis penelitian yang menjelaskan hubungan antara variabel status gizi dan preeklampsia dimana peneliti hanya melakukan pengamatan saja tanpa memberikan perlakuan pada responden. Penelitian dilakukan dengan pendekatan cross sectional yaitu dimana peneliti melakukan pengumpulan variabel tentang status gizi dan pre eklamsia dilakukan pada waktu yang sama.

Populasi penelitian adalah semua ibu hamil trimester III (usia kehamilan 28 - 40 minggu) yang melakukan pemeriksaan kehamilan di Puskesmas Sidotopo Wetan Surabaya sebesar 35 orang. Sampel penelitian sebesar 30 orang yang di ambil dengan teknik simple random sampling yaitu pengambilan sampel secara random dengan menggunakan undian berdasarkan nomer kunjungan responden.

\section{HASIL}

Tabel 1: Distribusi Responden Menurut Umur ibu pada bulan Juni di Puskesmas Sidotopo Wetan Surabaya

\begin{tabular}{lccc}
\hline No. & $\begin{array}{c}\text { Umur } \\
\text { (tahun) }\end{array}$ & Frekuensi & $\begin{array}{c}\text { Persentas } \\
\mathrm{e}(\%)\end{array}$ \\
\hline 1. & $\leq 20$ & 2 & 6,7 \\
2. & $21-35$ & 20 & 66,6 \\
3. & $\geq 35$ & 8 & 26,7 \\
\hline & Total & 30 & 100 \\
\hline
\end{tabular}

Tabel 2: Distribusi Responden Menurut hamil ke pada bulan Juni di Puskesmas Sidotopo Wetan Surabaya

\begin{tabular}{crrr}
\hline No. & Hamil ke & Frekuensi & \multicolumn{2}{c}{$\begin{array}{l}\text { Persentas } \\
\text { e }(\%)\end{array}$} \\
\hline 1. & & 2 & 6,7 \\
2. & 1 & 2 & 90,0 \\
3. & $2-4$ & 27 & 3,3 \\
\hline & $>4$ & 1 & 100 \\
\hline
\end{tabular}

Tabel 3: Distribusi Responden Menurut pekerjaan pada bulan Juni di Puskesmas Sidotopo Wetan Surabaya

\begin{tabular}{|c|c|c|c|}
\hline No. & Pekerjaan & $\begin{array}{c}\text { Freku } \\
\text { ensi }\end{array}$ & $\begin{array}{l}\text { Persentas } \\
\mathrm{e}(\%)\end{array}$ \\
\hline 1. & Tidak Bekerja & 21 & 70 \\
\hline 2. & Bekerja & 9 & 30 \\
\hline & Total & 30 & 100 \\
\hline
\end{tabular}


Tabel 4: Distribusi Responden Menurut riwayat DM ke pada bulan Juni di Puskesmas Sidotopo Wetan Surabaya

\begin{tabular}{cccc}
\hline No & $\begin{array}{c}\text { Riwayat } \\
\text { DM }\end{array}$ & Frekuensi & $\begin{array}{l}\text { Persentas } \\
\mathrm{e}(\%)\end{array}$ \\
\hline 1. & Tidak Ada & 23 & 76,6 \\
2. & Ada & 7 & 23,3 \\
\hline & Total & 30 & 100 \\
\hline
\end{tabular}

Tabel 5: Distribusi Responden Menurut riwayat hipertensi ke pada bulan Juni di Puskesmas Sidotopo Wetan Surabaya

\begin{tabular}{cccc}
\hline No & $\begin{array}{c}\text { riwayat } \\
\text { Hipertensi }\end{array}$ & Frekuensi & $\begin{array}{l}\text { Persentase } \\
(\%)\end{array}$ \\
\hline 1. & Tidak Ada & 26 & 86.7 \\
2. & Ada & 4 & 13.3 \\
\hline & Total & 30 & 100
\end{tabular}

Tabel 6: Distribusi Responden Menurut Penghasilan keluarga perbulan pada bulan Juni di Puskesmas Sidotopo Wetan Surabaya

\begin{tabular}{lccc}
\hline No & $\begin{array}{c}\text { Penghasilan } \\
\text { keluarga } \\
\text { perbulan }\end{array}$ & Frekuensi & $\begin{array}{c}\text { Persentase } \\
(\%)\end{array}$ \\
\hline 1. & $<2.710 .000$ & 7 & 23,3 \\
2. & $2.710 .000-$ & 20 & 66,7 \\
& 5.000 .000 & & 10 \\
3. & $>5.000 .000$ & 3 & 100 \\
\hline & Total & 30 & \\
\hline
\end{tabular}

Tabel 7: Distribusi Responden Menurut Status Gizi pada bulan Juni di Puskesmas Sidotopo Wetan Surabaya

\begin{tabular}{lccc}
\hline N & Status gizi & Frekuensi & $\begin{array}{c}\text { Persentase } \\
(\%)\end{array}$ \\
\hline o. & Kurang & 2 & 6,7 \\
2. & Normal & 13 & 43,3 \\
3. & Lebih & 15 & 50 \\
\hline & Total & 30 & 100 \\
\hline
\end{tabular}

Tabel 8: Distribusi Responden Menurut preeklampsia pada bulan Juni di Puskesmas Sidotopo Wetan Surabaya

\begin{tabular}{cccc}
\hline No. & Preeklampsia & $\begin{array}{c}\text { Freku } \\
\text { ensi }\end{array}$ & $\begin{array}{c}\text { Persentas } \\
\text { e }(\%)\end{array}$ \\
\hline 1. & $\begin{array}{c}\text { Tidak } \\
\text { preeklampsia }\end{array}$ & 18 & 60 \\
2. & Preeklampsia & 12 & 40 \\
\hline & Total & 30 & 100 \\
\hline
\end{tabular}

Tabel 9: Tabulasi silang pengaruh status gizi dengan kejadian preeklampsia pada ibu hamil

trimester III di Puskesmas Sidotopo Wetan Surabaya

\begin{tabular}{lcccccc}
\hline \multirow{2}{*}{$\begin{array}{l}\text { status } \\
\text { gizi }\end{array}$} & \multicolumn{4}{c}{ Preeklampsia } & \multirow{2}{*}{ Jumlah } \\
\cline { 2 - 5 } & $\mathrm{N}$ & $\%$ & $\mathrm{~N}$ & $\%$ & $\mathrm{~N}$ & $\%$ \\
\hline Kurang & 0 & 0 & 2 & 100 & 2 & 100 \\
Normal & 7 & 53,8 & 6 & 46,2 & 13 & 100 \\
Lebih & 11 & 73,3 & 4 & 26,7 & 15 & 100 \\
\hline Jumlah & 18 & 60 & 12 & 40 & 30 & 100 \\
\hline
\end{tabular}

\section{PEMBAHASAN}

Berdasarkan hasil menunjukkan bahwa setengah (50\%) dalam kategori status gizi lebih. Pada indeks masa tubuh ibu sebelum hamil normal kebanyakan saat hamil ibu mengalami kenaikan berat badan. Keadaan tubuh seseorang yang mengalami kenaikan berat badan yang terjadi karena kelebihan jumlah asupan energi yang disimpan dalam bentuk cadangan berupa lemak. Sesuai dengan teori Sediaoetama (2004) status gizi lebih keadaan dimana konsumsi kalori yang tidak seimbang dengan kebutuhan energi, dimana yang konsumsi melebihi dari apa yang dibutuhkan oleh tubuh Faktor yang mempengaruhi status 
gizi menurut Hermawan (2009) yaitu: umur, pekerjaan dan status ekonomi.

Berdasarkan data tentang umur responden menunjukkan bahwa dari 30 responden sebagian besar $(66,6 \%)$ mempunyai umur 21-35 tahun. Pada usia reproduksi semakin tua umur ibu hamil kebutuhan nutrisi dan energinya semakin meningkat. Sesuai dengan teori Hermawan (2009) usia ibu ketika hamil dapat berpengaruh terhadap gizi ibu hamil, semakin tua usia ibu, maka semakin tinggi pula energi yang dibutuhkan saat hamil.

Pada tabel 3 menunjukkan bahwa sebagian besar (70\%) ibu tidak bekerja. Jika ibu hamil bekerja akan menganggu kehamilannya, dan jika aktivitas ibu hamil tinggi, kebutuhan energinya juga akan semakin tinggi. Beban aktivitas atau kerja akan mempengaruhi metabolisme energi di dalam tubuh. Jika ibu hamil memiliki banyak aktivitas, maka akan lebih banyak energi yang digunakan untuk dapat melakukan aktifitasnya (Hermawan, 2009).

Tabel 5 menunjukkan bahwa sebagian besar $(66,7 \%)$ responden penghasilan keluarga berkisar 2.710.000 - 5.000.000. Penghasilan keluarga diatas UMK surabaya atau lebih, tidak menutup kemungkinan bahwa ibu hamil tersebut mampu dalam status ekonominya, mampu memenuhi kebutuhan sehari-hari dan mampu mencukupi kebutuhan gizi keluarga.Menurut Hidayati (2006) status ekonomi dapat mempengaruhi perubahan status gizi karena penyediaan makanan bergizi membutuhkan pendanaan yang tidak sedikit. Oleh karena itu, masyarakat dengan kondisi perekonomian tinggi akan meningkatkan kemampuan daya beli sehingga dapat menenuhi kebutuhan gizi keluarganya.
Pada tabel 8 menunjukan bahwa sebagian besar (60\%) ibu tidak mengalami preeklampsia. Hal ini karena didapatkan sebagian besar ditemukan ibu hamil dengan tekanan darah normal, tidak ada tanda gejala preeklampsia dan protein urin negatif. Hipertensi dan proteinuria merupakan gejala yang gejala khas dari preeklamsi, dan jika disertai keluhan nyeri kepala hebat, gangguan pengelihatan/pandangan mata kabur, atau nyeri epigastrium, maka termasuk pre eklamsi berat (Sarwono 2009).

Tabel 1 menunjukkan bahwa $65,7 \%$ responden berada pada rentang umur reproduksi yaitu 21-35 tahun, pada umur tersebut organ reproduksi telah matang. Organ reproduksi yang telah matang merupakan umur reproduksi normal, maka semua organ reproduksi ini dapat berfungsi dengan baik dalam kehamilan sehingga sedikit kemungkinan ditemukan komplikasi kehamilan yang salah satunya adalah preeklampsia. Kehamilan yang terjadi pada wanita usia kurang dari 20 tahun atau lebih dari 35 tahun mempunyai resiko 3-4 kali lipat terjadi preeklampsia dibandingkan usia reproduksi yaitu usia 21-35 tahun. (Karkata, 2006)

Pada tabel 4 dapat dilihat bahwa hampir seluruh responden $(76,6 \%)$ tidak mempunyai riwayat diabetus militus. Hal ini menunjukkan bahwa, meskipun penyakit diabetes merupakan faktor predisposisi dari penyakit pre eklamsi, namun pada kenyataannya banyak kasus pre eklamsi yang terjadi pada ibu hamil tanpa ada riwayat diabetes. Hal tersebut dimungkinkan banyaknya faktor predisposisi terjadinya preeklamsi selain diabetes. (Wiknjosastro, H. 2006) 
Hasil uji Mann Whitney dengan $\alpha=0,05$ didapatkan $\rho=0,079>0,05$, artinya $\mathrm{H}_{\mathrm{o}}$ diterima, kesimpulannya tidak ada hubungan antara status gizi dengan kejadian preeklampsia pada ibu hamil trimester III di Puskesmas Sidotopo Wetan Surabaya.

Pada tabel 9 tentang tabulasi silang antara status gizi dengan kejadian preeklampsiadiketahui bahwa sebagian besar $(53,3 \%)$ responden terjadi pada ibu hamil yang status gizi lebih, dan pada tabel 5.8 didapatkan sebagian besar $(60 \%)$ ibu hamil tidak mengalami preeklampsia. Pada kenyaatannya dari hasil penelitian ditemukan sebagian besar ibu dengan status gizi lebih tidak mengalami kejadian preeklampsia, justru sebagian besar status gizi kurang dan normal mengalami preeklampsia, hasil ini tidak sesuai dengan teori Chapman (2006) bahwa perempuan obesitas memiliki resiko empat kali lipat terjadi preeklampsia.

Dapat disimpulkan bahwa ibu dengan status gizi lebih tidak berpengaruh terhadap kejadian preeklampsia. Hal ini bisa dikarenakan kejadian preeklampsia dipengaruhi oleh banyak faktor yaitu molahidatidosa yang dapat menyebabkan preeklampsia karena merupakan degenerasi trofoblas berlebihan. Paritas juga meningkatkan resiko preeklamsi, pada ibu yang baru pertama hamil (nulipara) resiko preeklampsia lebih tinggi daripada multipara, terutama nulipara muda. Di sisi lain, pada kehamilan nulipara hampir 20\% mengalami hipertensi sebelum, selama bersalin dan masa nifas, kemungkinan karena adanya reaksi bilogis tubuh terhadap villi khorialis untuk pertama kalinya. Diabetes mellitus disertai kelainan ginjal/vaskular primer juga merupakan predisposisi terjadinya preeklampsia ringan, selain itu frekuensi preeklamsia lebih sering terjadi pada kehamilan gemelli karena uterus yang membesar berlebihan. Ibu umumnya mengeluh sesak nafas, varises dan edema pada tungka, serta ditemukannya proteinurin. Selain factor tersebut, umur juga dapat meningkatkan resiko terjadinya pre eklamsi, karena wanita umur diatas 35 tahun sudah rentan mengalami hipertensi laten, sehingga semakin beresiko mengalami preeklamsi jika terjadi kehamilan pada usia tersebut.

\section{SIMPULAN}

Berdasarakan penelitian yang telah diakukan, didapatkan bahwa pada ibu hamil trimester III di Puskesmas Sidotopo Wetan Surabaya:

1. Sebagian besar memiliki status gizi lebih.

2. Sebagian besar tidak mengalami preeklampsia.

3. Tidak ada pengaruh status gizi dengan kejadian preeklampsia

\section{SARAN}

\section{Bagi tenaga kesehatan}

Bagi tenaga kesehatan khususnya bidan dapat meningkatkan promosi, edukasi pelayanan kesehatan pada ibu hamil, ibu melahirkan maupun ibu menyusui tentang pentingnya kejadian preeklampsia pada ibu hamil terutama ibu dengan status gizi lebih.

\section{Bagi Tempat Penelitian}

Diharapkan lebih ditingkatkan lagi untuk pengetahuan ibu hamil tentang terjadinya preeklampsia dan penyuluhan tentang pentingnya faktor 
resiko terjadinya preeklampsia pada ibu hamil, diharapkan juga agar petugas kesehatan maupun kaderkader serta masyarakat setempat bisa memperbaiki cara pola hidup ibu hamil.

\section{DAFTAR PUSTAKA}

Alimul,Aziz.2007. Metode Penelitian Kebidanan Teknis Analisis Data. Yogyakarta

:SalembaMedika

Andriana. E. 2007. Melahirkan Tanpa Rasa Sakit. Jakarta : Bhuana Ilmu Populer

Atikah, Proverawati. 2011. Imu Gizi untuk Keperawatan dan Gizi Kesehatan. Yogyakarta : Nuha Medika

Bobak, Lowdermik dan Jensen. 2005. Buku Ajar Keperawatan Maternitas. Jakarta: EGC

Chapman, Vicky. 2006. Asuhan Kebidanan Persalinan dan Kelahiran.Jakarta : EGC.

Efindri.Ns. 2011. Metodologi Penelitian Kesehatan. Jakarta : Baduose Media Jakarta.

Karkata, MK. 2006. Faktor resiko terjadinya hipertensi dalam kehamilan, Indonesian Journal of Obstetrics and Gynecology, vol.30, no. 1 , hal55-57

Kasdu, 2007. Gizi dan Kesehatan Masyarakat. Jakarta : Raja Grafindo Persada

Kristiyanasari, Weni 2010. Gizi Ibu Hamil. Yogyakarta : Nuha Medika.
Kusmiyati. 2010. Perawatan Ibu Hamil. Yogyakarta : Fitramaya

Manuaba, IBG, dkk. (2010). Ilmu kebidanan Penyakit Kandungan dan $K B$. Jakarta: EGC

Marmi.Fatmawati, E. Suryaningsih, M. 2011. Asuhan Kebidanan Patologi.Yogyakarta : Pustaka Pelajar.

Maryunani, Anik. 2012. Asuhan Kegawat Daruratan Dalam Kebidanan. Trans Info Media. Jakarta

Mochtar, Rustam. 2012. Sinopsis Obstetri. Jakarta : Buku Kedokteran EGC

Paath. 2005. Gizi Dalam Kesehatan Reproduksi. Jakarta : EGC

Patricia W. Ladewig, M. L. 2006. Buku Saku Asuhan Ibu dan Bayi Baru Lahir .Jakarta : EGC

Purnomo,W. Bramantoro, T. 2013. 36 Langkah Praktis Sukses Menulis Karya Tulis Ilmiah. Surabaya : Revka Petra Media.

Saimin, J. 2006. Hubungan Antara Berat Badan Lahir Dengan Status Gizi Ibu Berdasarkan Ukuran Lingkar Lengan Atas. Bagian Obstetri Ginekologi Kedokeran Universitas Hasanudin, Makasar

Saryono, Ari. 2011. Metodologi Penelitian Kesehatan DIII, DIV, S1 dan S2. Yogyakarta : Nuha Medika 
Supariasa,I Dewa Nyoman. 2012. Penilaian Status Gizi. Jakarta : EGC

Wibisono, Hermawan. 2009. Solusi

Sehat Seputar Kehamilan.

Jakarta : Agro Media Pustaka

Wiknjosastro, Hanifa, 2006 Ilmu

Kebidanan Jakarta: YBH 